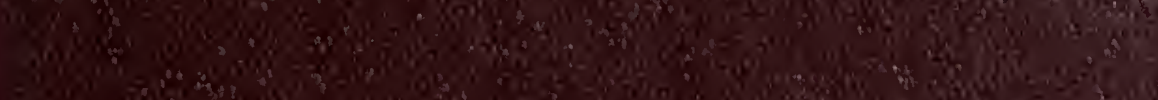

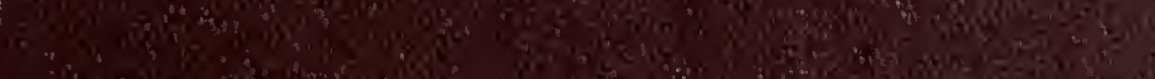
A t

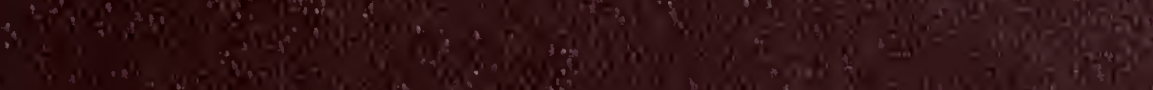
at

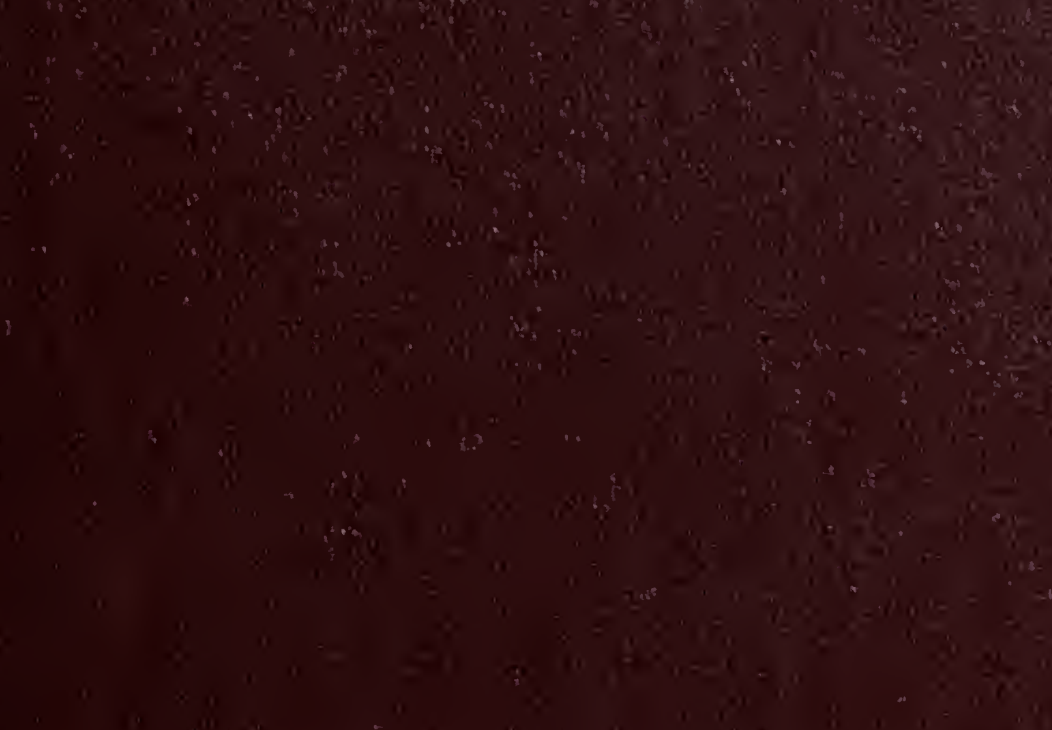




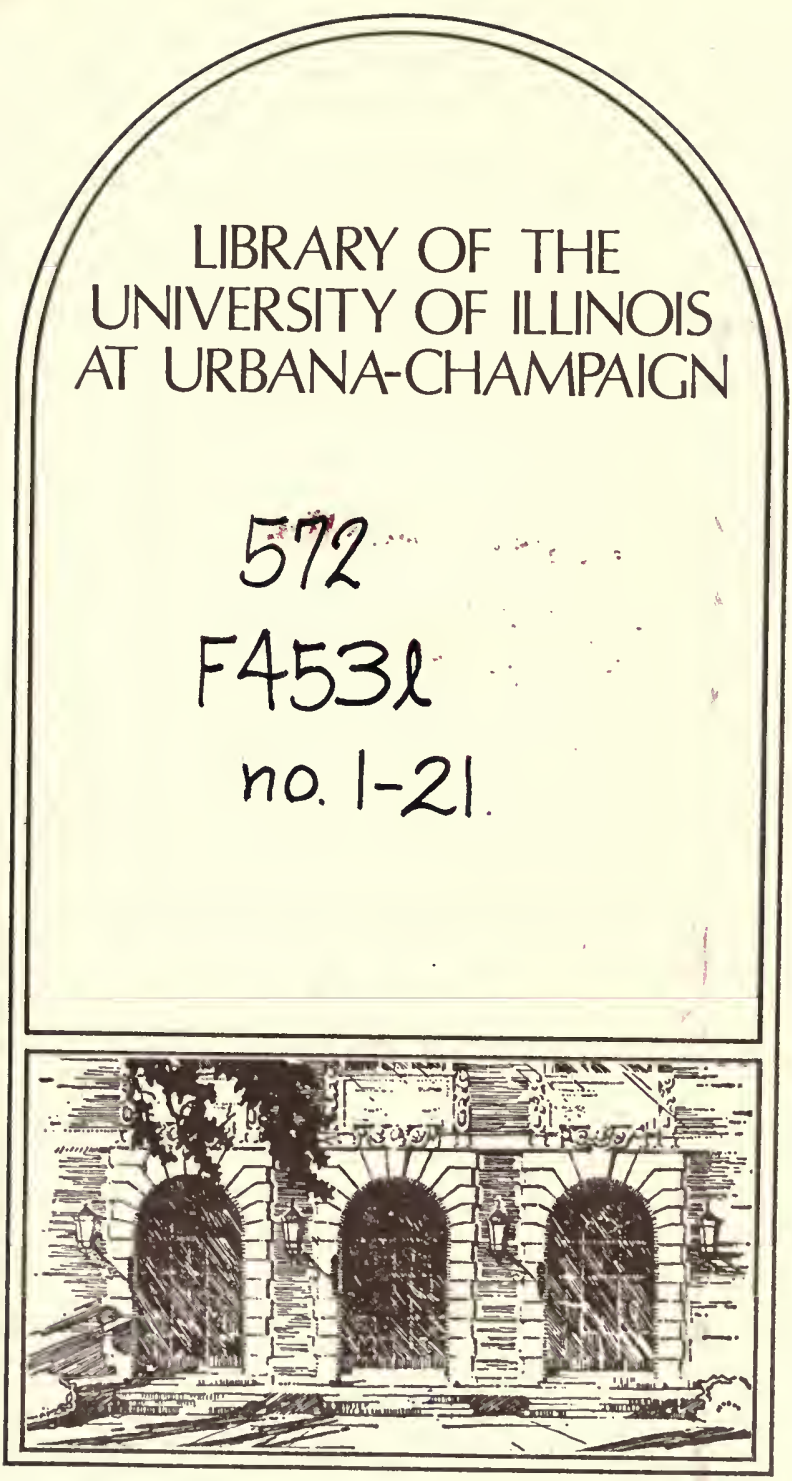


The person charging this material is responsible for its return to the library from which it was withdrawn on or before the Latest Date stamped below.

Theft, mutilotion, and underlining of books are reosons for disciplinory oction ond moy result in dismissol from the University.

To renew coli Telephone Center, 333-8400

UNIVERSITY OF ILLINOIS MIBRARY AT URBANA.CHAMPAIGN =

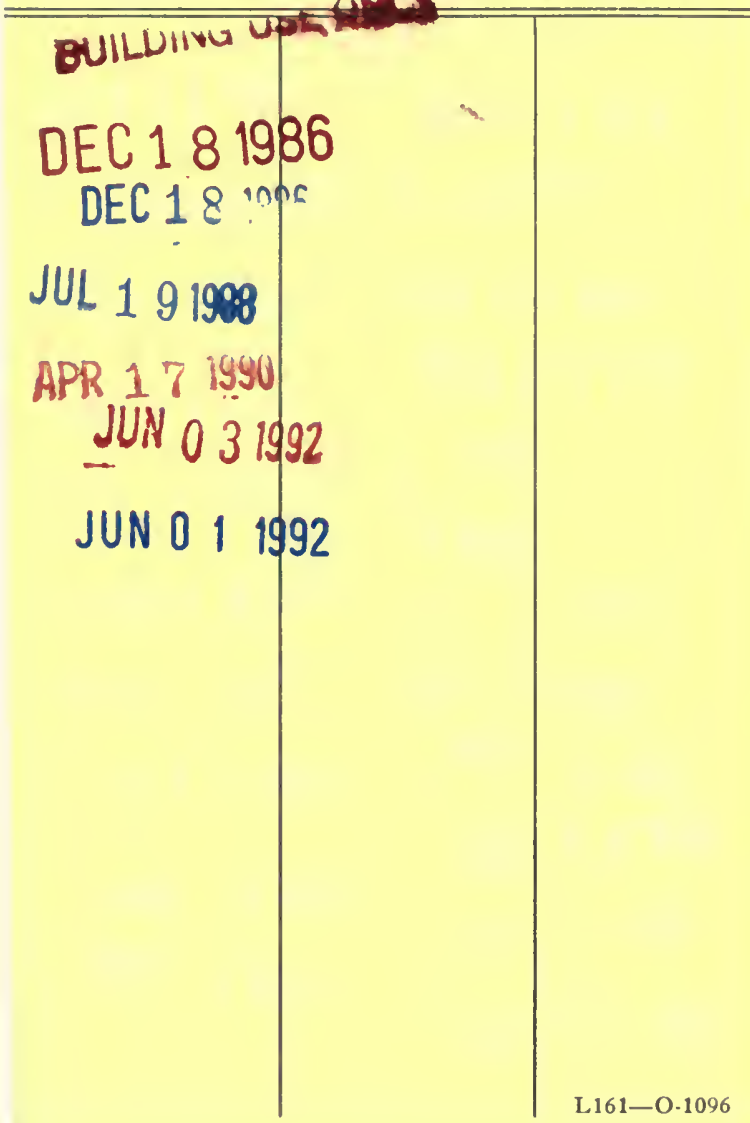





\section{PHILIPPINE FORGE GROUP}

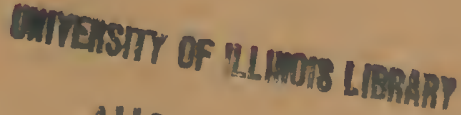 SUG $16 \quad 1922$

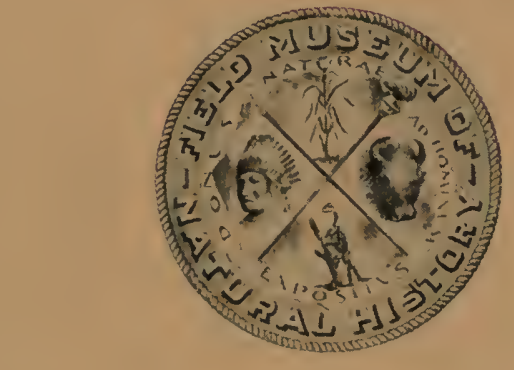

FIELD MUSEUM OF NATURAL HISTORY CHICAGO 

GWIVERSTTY OF ILLLMOIS LIBMANT AUG 161922 


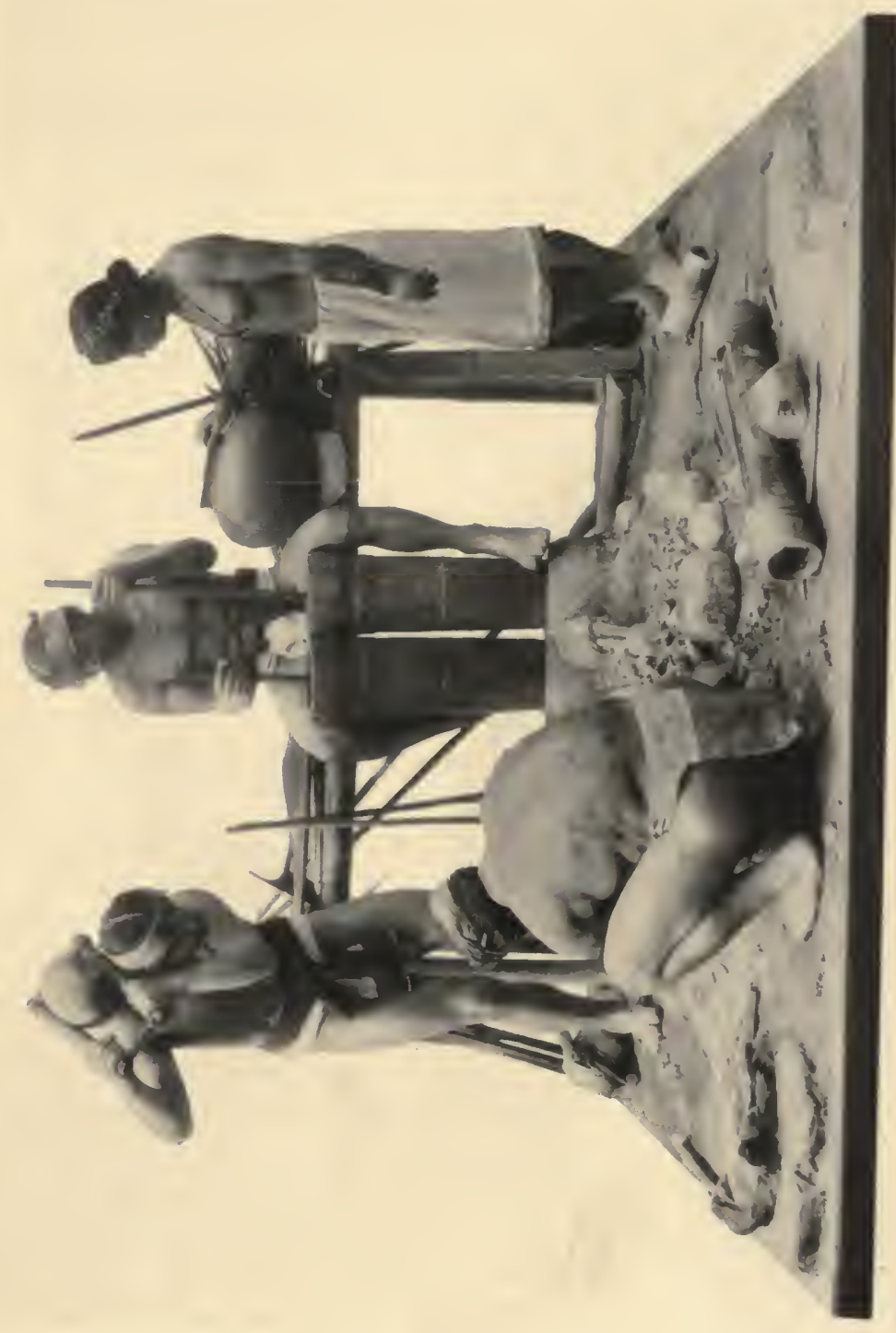




\section{Fas3l \\ no.2.}

Field Museum of Natural History

DEPARTMENT OF ANTHROPOLOGY

Chicago, 1922

\section{The Philippine Forge Group}

(Hall 9, Case 21)

The finest headaxes and spear-points made in northwestern Luzon (Philippine Islands) come from Balbalasang and the other villages of the upper Buklok, or Saltan river, just at the boundary between the Tinguian and Kalinga tribes. It is of interest to note that in this and in other more or less isolated districts of the Philippines we find the peculiar method of iron-working, which is here described, while along the coast it has vanished, or is of little importance.

The same condition is found in Assam, Burma, Eastern Madagascar, Sumatra, Java, Borneo, and other islands to the east, making it evident that iron-working was an ancient art throughout Malaysia, and that it spread from a common center.

The Tinguian iron-workers do not mine or smelt the native ore, although there is an abundance in their territory, but secure the metal from Chinese traders on the coast. In view of the fact that many of the pagan tribes of the islands to the south do now, or did until recently, smelt the ore, it seems altogether probable that the Philippine tribesman also had knowledge of the process, but gave it up when trade relations made such arduous work unnecessary.

The forge here illustrated comes from Inalagan, one of the small settlements which makes up the community of Balbalasang ("the town of many maidens"). It stood in a small structure with grass roof, but without sides or floor. At one end of such a structure is a bamboo 
bench, in front of which stands the bellows-two upright cylinders made of logs hollowed out. In each of these is a piston or plunger, at the lower end of which is a wooden ring packed with corn husks and chicken feathers. When a plunger is pushed downward in the cylinder, it compresses the air and forces it out of the small opening in the base, but when it is drawn up, the packing collapses and allows it to be raised without effort. These pistons are worked alternately so that one is rising, while the other is falling.

Two bamboo tubes, attached to the bellows, conduct the air into a cylinder of fire clay, and this in turn carries it into the charcoal fire. These bamboos fit loosely into the clay cylinder, thus taking the place of valves and preventing the drawing of the fire back into the bellows.

Near to the hearth is a stone anvil, while a heavy stone hammer, a small stone hammer, and pinchers of the same material complete the outfit. The fire is lighted, and the operator sitting on the bench raises and lowers the plungers in the cylinders until the fire burns brightly; then the smith puts the metal into the coals, and allows it to remain until it reaches a white heat. It is then removed and placed on the anvil, where his helper beats it out with the large hammer. This is a stone weighing twenty or more pounds, fitted inside the handles, so that it can be used with both hands. As a rule, it is swung between the legs, and is allowed to strike the metal as it descends, but some of the men raise it above the shoulder and strike a much more powerful blow. If two pieces of metal are to be welded together, as is often the case when broken cauldrons are used, they are laid one overlapping the other, and are held together with damp fire clay. In this condition they are placed in the fire and heated, being then 
beaten together. It often takes several firings to bring about a perfect weld.

After the initial shaping, the smith completes the work with the small hammer, and the blade is again inserted in the fire and brought to a white heat. Then the smith withdraws it and watches it intently, until the white tone begins to turn to a greenish-yellow, when he plunges it into water. The tempered blade is now smoothed down with sandstone, and is whetted to a keen edge. Headaxes, spear heads, adzes, a few knives, and the metal ends for the spear-shafts are the principal products of the forge.

The blades are by no means of equal temper or perfection, but the smiths of the Tinguian-Kalinga border villages seldom turn out poor weapons and, as a result, their spears and headaxes have a wide distribution over northwestern Luzon.

The material and data for this group were gathered by F. C. Cole in connection with the Robert F. Cummings Philippine Expedition during the years 1907-08. The modeling is the work of Clyde Gardner.

\section{REFERENCES TO IRON-WORKING IN MALAYSIA}

Cole, Wild Tribes of Davao District, Mindanao (Field Museum of Natural History, Anthropological Series, Vol. XII, No. 2, pp. 82-83).

Hose and McDougall, Pagan Tribes of Borneo, Vol. I, pp. 194-5. Raffles, History of Java, Vol. I, pp. 192-3.

MARDSEn, History of Sumatra, 3d ed., p. 181.

Ferrais, Burma, p. 105.

RockHill, T'oung Pao, Vol. XVI, 1915, pp. 268-269.

Blair and Robertson, The Philippine Islands, Vol. III, p. 299; Vol. XL, p. 48.

BECcARI, Wanderings in the Great Forests of Borneo, pp. 282-283.

F. C. Cole. 
MANERSITY OF ILLMOIS LORTARI

$$
\text { AUG } 161922
$$





UNIVERSTYY OF ILINOIS-URBANA 